\title{
Diversity of cavity-nesting bees (Hymenoptera: Apoidea) within apple orchards and wild habitats in the Annapolis Valley, Nova Scotia, Canada
}

\author{
Cory S. Sheffield ${ }^{1,2}$ \\ Department of Environmental Biology, University of Guelph, Guelph, Ontario, Canada N1G 2W1, \\ and Agriculture and Agri-Food Canada, 32 Main Street, Kentville, Nova Scotia, Canada B4N 1J5 \\ Peter G. Kevan \\ Department of Environmental Biology, University of Guelph, Guelph, Ontario, Canada N1G 2W1 \\ Sue M. Westby, Robert F. Smith \\ Agriculture and Agri-Food Canada, 32 Main Street, Kentville, Nova Scotia, Canada B4N 1J5

\begin{abstract}
Solitary cavity-nesting bees, especially trap-nesting Megachilidae, have great potential as commercial pollinators. A few species have been developed for crop pollination, but the diversity, abundance, and potential pollination contributions of native cavity-nesting bees within agricultural systems have seldom been assessed. Our objectives were to compare the diversity and fecundity of cavity-nesting bees in Nova Scotia in natural ecosystems with those in apple orchards under three levels of management, using trap nests, and to determine whether any native bees show promise for development as pollinators. Our results show that species richness and numbers of bees reared from trap nests in commercially managed orchards, abandoned orchards, and natural habitats were similar, and species' compositional patterns were not unique to specific habitats. Trap nests can be used to increase and maintain cavity-nesting bee populations within Nova Scotia apple orchards. Osmia tersula Cockerell (Megachilidae), which accounted for almost $45 \%$ of all bees captured and was the most abundant species nesting in all habitats evaluated, should be assessed for potential as a commercial pollinator of spring-flowering crops. The influence of natural cavities on bee species richness in trap-nesting surveys is also discussed.
\end{abstract}

Résumé-Les abeilles solitaires qui nichent dans les cavités, particulièrement les Megachilidae qui logent dans les nids-pièges, représentent un important potentiel de pollinisateurs commerciaux. Quelques espèces ont été utilisées pour la pollinisation des cultures, mais on a rarement évalué la diversité, l'abondance et la contribution potentielle à la pollinisation des abeilles qui nichent dans les cavités dans les systèmes agricoles. Notre objectif est de comparer à l'aide de nids-pièges la diversité et la fécondité des abeilles qui nichent dans les cavités dans les écosystèmes naturels et dans des pommeraies gérées sous trois régimes différents en Nouvelle-Écosse, ainsi que de déterminer s'il y a des abeilles indigènes qui offrent un potentiel pour servir à la pollinisation. Nos résultats montrent que la richesse spécifique et le nombre d'abeilles obtenues dans les nids-pièges sont semblables dans les pommeraies sous gestion commerciale, dans les pommeraies abandonnées et les habitats naturels; de plus, les patrons de composition spécifique ne sont pas propres aux différents habitats. Dans les pommeraies de Nouvelle-Écosse, les nidspièges peuvent servir à augmenter et à maintenir les populations d'abeilles qui nichent dans les cavités. Osmia tersula Cockerell (Megachilidae), qui représente presque $45 \%$ de toutes les abeilles capturées et qui est l'espèce la plus abondante à nicher dans tous les habitats étudiés, devrait être évalué en vue d'une utilisation éventuelle comme pollinisateur des cultures qui fleurissent au printemps. Nous discutons aussi de l'influence des cavités naturelles sur la richesse spécifique des abeilles dans les inventaires faits à l'aide de nids-pièges.

[Traduit par la Rédaction]

Received 7 August 2007. Accepted 19 December 2007.

${ }^{1}$ Present address: Department of Biology, York University, 4700 Keele Street, Toronto, Ontario, Canada M3J 1P3.

${ }^{2}$ Corresponding author (e-mail: corys@yorku.ca). 


\section{Introduction}

Bees (Hymenoptera: Apoidea) are the most important pollinators (Kevan and Baker 1983; Free 1993), and releasing them into agricultural landscapes is the fastest and most effective way to provide sufficient numbers to meet the pollination requirements of many crops. This is achieved most often with the use of honey bee, Apis mellifera L. (Apidae: Apini), colonies (Free 1993), and more recently with managed colonies of bumble bees (Apidae: Bombini), which are commercially available year-round and have proved invaluable in greenhouse settings (Kevan et al. 1991; Thorp 2003, and references therein). In tropical areas, stingless bee (Apidae: Meliponini) colonies have also shown potential for management as crop pollinators (Heard 1999).

For solitary bees, nesting biology often dictates the ease with which they can be developed and managed for pollination; although many groundnesting species are important crop pollinators (Free 1993), only the alkali bee, Nomia melanderi Cockerell (Halictidae: Nomiinae), has been extensively studied and successfully developed for commercial pollination of any crop (Free 1993; Stephen 2003, and references therein). Cavitynesting bees, especially those of the family Megachilidae, have shown the greatest potential for development as manageable pollinators, as many species readily accept artificial nesting materials, including trap nests (Krombein 1967; Stubbs and Drummond 2001; Cane et al. 2007). Trap nests have been used to study nesting biology (e.g., Krombein 1967), develop and evaluate potential crop pollinators (e.g., Torchio 2003), conduct studies of species diversity (e.g., SteffanDewenter 2002, 2003), and provide additional nesting sites for increasing and conserving bee populations (e.g., Stubbs and Drummond 2001).

Several megachilid bee species show floral preferences and can be exploited for pollination of specific crops. Examples include Megachile rotundata (Fabr.) for alfalfa pollination (Stephen 2003) and Osmia Panzer species for tree fruits (Bosch and Kemp 2001; Torchio 2003). However, the commercial status of Osmia spp. in general is not known (Stephen 2003), although they have certainly shown great potential in previous studies of pollination of tree fruit crops, including apple (Bosch and Kemp 2001; Torchio 2003).

Many megachilid bees can be trap-nested in a multitude of habitats and subsequently released back into agricultural systems (Torchio 2003). Unfortunately, agricultural practices often make these systems unfavourable for many beneficial organisms through pesticide use (Kevan 2001) as well as causing loss of natural habitat and plant diversity through fragmentation (Banaszak 2000; Steffan-Dewenter 2002; Steffan-Dewenter and Leschke 2003), altering natural margins (Corbet 1995; Marshall and Moonen 2002), and reducing nesting-site availability (Westrich 1996). Furthermore, the impact of agricultural practices on overall species richness and subsequent utilization of cavity-nesting bees for pollination within these systems has seldom been assessed.

The main objective of our study was to compare the diversity and relative fecundity of cavitynesting bees within apple orchards in Nova Scotia under three levels of management with those of bees in natural ecosystems. Our expectations were that richness and abundance of cavity-nesting bees would be lowest in sites within habitats with the most intense levels of agricultural management, and would increase with decreasing habitat management; high similarity among sites within each habitat type and low similarity among habitats were expected. A second objective was to determine if any indigenous bee species show promise for development as managed pollinators. To address these objectives we used trap nests to conduct a 3year survey of cavity-nesting bees within four habitat types: three were apple-orchard systems and one comprised non-agricultural habitats.

\section{Materials and methods}

\section{Study sites}

In total, 23 sites within Nova Scotia's main agricultural and horticultural region, the Annapolis Valley (Fig. 1), were used during the 3 years of this study. For various reasons not all sites could be used each year; 20 were used in 2000 and 19 in 2001 and 2002 (for details see Appendix A). The sites represented four habitat types: (1) COMM-A: sites A1-A5, which were commercially managed apple orchards within agricultural landscapes surrounded by adjacent orchard blocks or other agricultural crops, etc., routinely mowed and (or) treated with herbicides, and subject to pesticide use; (2) COMM-B: sites B1-B5, which were commercially managed orchard blocks isolated from other agricultural areas and (or) usually surrounded by adjacent woodland or non-agricultural land, also routinely mowed and 
Fig. 1. Map of Nova Scotia, Canada. The insert (44.93339-45.31580 $\left.\mathrm{N}, 64.19303-65.90454^{\circ} \mathrm{W}\right)$ shows study sites in four different habitat types in the Annapolis Valley ( $\diamond$, sites in COMM-A habitat; $\diamond$, sites in COMMB habitat; $\bigcirc$, sites in ABAND habitat; $\bigcirc$, sites in WILD habitat). For details of sites see Appendix A.



(or) treated with herbicides, and subject to pesticide us; (3) ABAND: sites C1-C6, which were abandoned and (or) unmanaged orchard sites that had not been mowed or sprayed with pesticides for at least 10 years; and (4) WILD: D1-D7, which were mixed natural meadow/woodland habitats at least $5 \mathrm{~km}$ from any other sites. Sites within each habitat were at least 5 ha, and were selected to represent varying levels of management and floral-resource availability, COMM-A sites representing one extreme (assumed low floral-resource availability, based on management practices and inspection) and WILD habitats the other (a variety of native floral resources available throughout the season). Site selection was facilitated by data collected for "Tree Fruit Census of the Annapolis Valley" (Craig 1998), particularly the "Orchard Mapping Project" conducted by the Nova Scotia Department of Agriculture and Marketing in 1995, and through personal scouting and communication with apple growers, integrated pest management consultants, researchers, and (or) extension staff.

\section{Methods of surveying cavity-nesting bees}

Trap nests were used to survey the diversity and abundance (i.e., overall fecundity) of cavitynesting bees in all the study sites. In 2000 each trap nest consisted of a tight bundle of paper nesting tubes (20 tubes each of $3,5,7$, and $9 \mathrm{~mm}$ internal diameter; all were $15 \mathrm{~cm}$ in length; Jonesville Papertube Corporation, Jonesville, Michigan) placed within a modified $2 \mathrm{~L}$ milk carton. The bundle was supported in the milk carton with foam insulation sprayed into the cavity surrounding the tube bundle and allowed to dry (Fig. 2A). For 2001 and 2002 a new design was developed because of problems with the previous design: the absence of spacing between individual nesting tubes (Fig. 2A) was believed to be a deterrent to nesting activity for some bee species (Bosch and Kemp 2001), and moisture getting into the surrounding cavity caused mould problems. For the new design, a front piece of $4 \mathrm{~cm}$ thick blue highdensity polystyrene foam was placed in the milk carton and nine tubes of each diameter were arranged in a grid pattern within each trap nest (Fig. 2B).

In all years, six trap nests were placed in each site 1-1.5 $\mathrm{m}$ above ground level, with southern exposure. Trap nests were fastened to trees or fence posts, or were attached to $1 \mathrm{~m}$ high plastic fencing stakes (Fig. 2B) along the periphery of the orchard sites. A strip of Tanglefoot ${ }^{\circledR}$ was placed on the supporting structure of each trap nest approximately $30 \mathrm{~cm}$ above the ground to prevent raiding by ants and 
Fig. 2. (A) Trap nest design used in 2000 but not in 2001-2002 because the absence of spacing between tubes was believed to discourage nesting. (B) Trap nest design used in 2001-2002; this particular trap is mounted on a fencing stake.
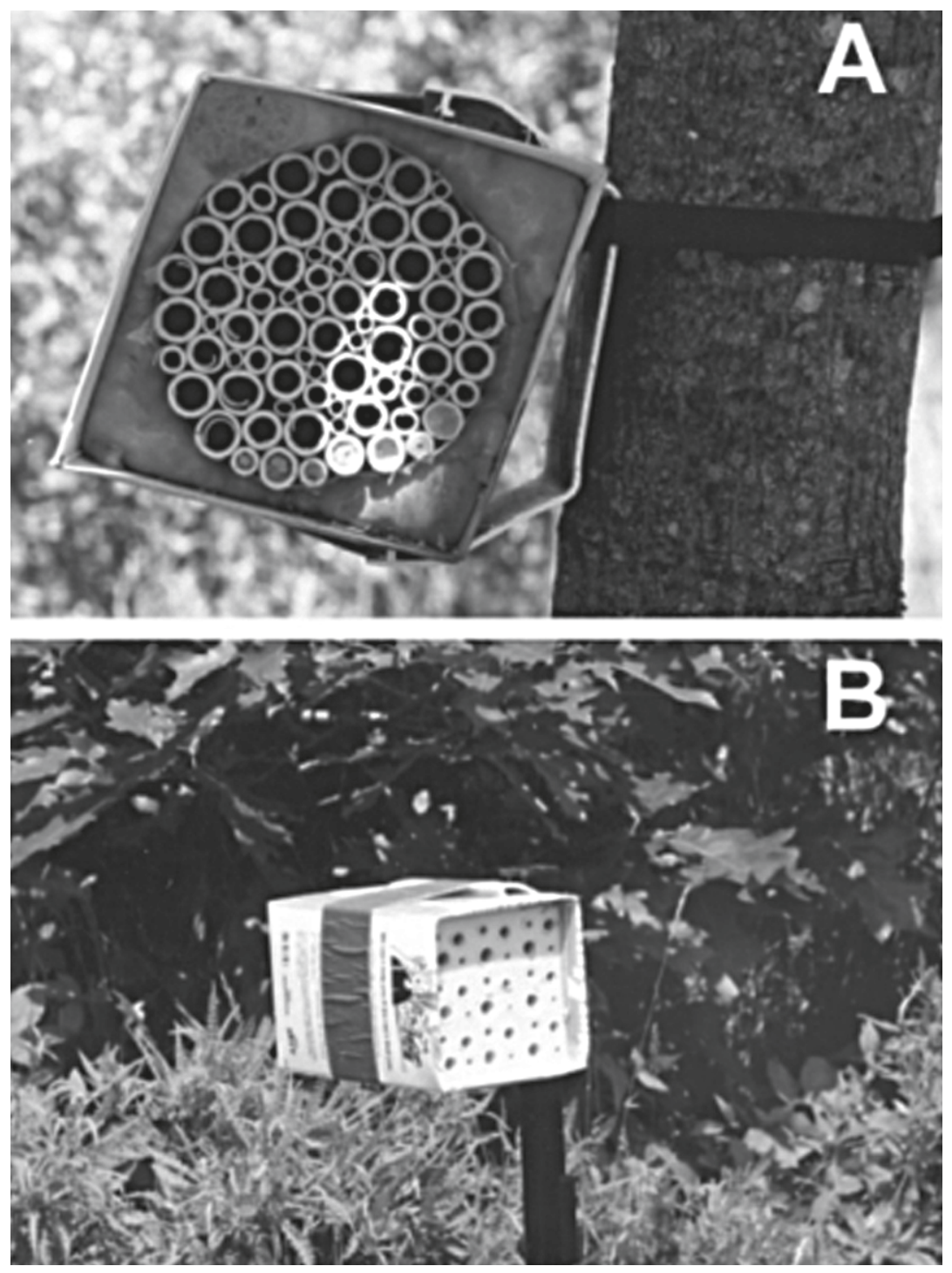

earwigs. In addition, all vegetation blocking nest entrances was removed throughout the season. Trap nests were put out in April (prior to bee flight) and removed in late September each year.

At the end of the bee flight season, trap nests were collected from all sites, labelled, and stored in a screened building until late October. Nesting tubes were then removed from trap nests, sorted according to tube size and type of nesting material collected by the occupants, and then placed in cold storage at $4{ }^{\circ} \mathrm{C}(60 \%-70 \% \mathrm{RH})$. In late winter (February-March), nesting tubes were placed in small transparent containers in an incubator at $30{ }^{\circ} \mathrm{C}$. The containers were checked daily for emergence. Emerged insects were collected and later prepared for identification. Total emergence time (in days) was recorded for each trap-nested bee. Specimens collected in this study are currently held in the Packer Bee Collection, York University, Toronto, Ontario. Synoptic collections of voucher species will be retained in the Packer Bee Collection and also placed in the Department of Environmental Biology, University of Guelph, Guelph, Ontario and the Canadian National Collection, Ottawa, Ontario. 


\section{Data analyses}

Trap nests as a sampling unit consist of nesting tubes containing related individuals (i.e., eggs laid by one nesting female); the "capture" data for individuals are therefore not independent. Therefore, taxon sampling curves and methods of comparison based on random and independent resampling of data (i.e., rarefaction) were deemed inappropriate. To summarize the relationship between the species collected and the number of individuals reared for each habitat type, rank-abundance plots were prepared using data pooled for all 3 years. Species richness and the number of bees reared for each habitat and year were compared using two-factor analysis of variance (ANOVA) (Minitab Inc. 2000); Tukey's test $(P=0.05)$ was used to examine possible pairwise differences. The BergerParker dominance index (Magurran 2004) was determined for each site, and habitat/years were compared by two-factor ANOVA as above. This index was chosen because it provides a comparable measure of dominance for the most abundant species within a site (Magurran 2004). Similarly, species dominance (SD) (i.e., total proportional abundance of each species) was determined using the following formula:

$$
\mathrm{SD}=\left(S_{i} / S_{\mathrm{tot}}\right) \times 100
$$

where $S_{i}$ represents the number of individuals of species $i$ and $S_{\text {tot }}$ represents all bees collected during the 3-year study. In addition, frequency of occurrence (FO) was calculated for the 3 years using the following formula (after Buschini 2006):

$$
\mathrm{FO}=\left(\mathrm{SM}_{i} / \mathrm{SM}_{\mathrm{tot}}\right) \times 100
$$

where $\mathrm{SM}_{i}$ represents samples containing species $i$ and $\mathrm{SM}_{\text {tot }}$ represents the total number of samples. For each species, FO was calculated at two levels for each habitat for all 3 years: (1) trap nests and (2) sites within each habitat.

Chi-square analysis (Zar 1999) was employed to determine within-habitat variability in productivity (i.e., total number of bees reared from each site within a habitat) for each year. Fecundity (i.e., number of bees per nesting tube) for each habitat was also compared using $\chi^{2}$ analysis (Zar 1999); expected values for each habitat were calculated using the following formula:

$$
\hat{E}=T_{\text {hab }} \times\left(N / T_{\text {tot }}\right)
$$

where $T_{\text {hab }}$ is the number of nesting tubes recovered in each habitat, $N$ is the total number of bees recovered, and $T_{\text {tot }}$ is the total number of nesting tubes recovered; data for all years were pooled.

To determine which habitats showed the highest levels of internal similarity (i.e., among sites within each habitat), values of Jaccard's incidencebased similarity index $\left(S_{\mathrm{J}}\right)$ (Magurran 2004) for all site-pair comparisons within each habitat for 2000-2002 were pooled and compared using ANOVA with Tukey's tests $(P=0.05)$ to examine the possible pairwise differences. Species composition was also compared among the sites using Jaccard's incidence-based dissimilarity index $\left(1-S_{\mathrm{J}}\right)$ for 2001-2002, calculated using Community Analysis Package 3.2 (Seaby et al. 2004). The resulting matrix was analyzed by means of cluster analysis using average linkage, and a dendrogram was produced. Cluster analysis was chosen over ordination techniques because there were a priori reasons for suspecting that the data would fall into four discrete groups based on the chosen habitat types (Seaby et al. 2004).

The nest tube diameter preference of each bee species was summarized using Levins' (1968) normalized niche breadth measure $(B)$. $B$ values ranged from 0.25 (the females of that species chose only nesting tubes of one diameter to provision) to 1.0 (nesting tubes chosen by a species were equally distributed across diameters).

\section{Results}

\section{Abundance and richness patterns}

Throughout the 3-year study period, 4102 individual bees representing two families and 18 species were reared from approximately 400 provisioned trap nest tubes from the sites surveyed, 5 of which were cleptoparasites from the megachilid genera Coelioxys Latreille and Stelis Panzer (Table 1). Hylaeus verticalis (Cresson) (Apoidea: Colletidae) and two megachilid species, Heriades carinata Cresson and its cleptoparasite Stelis coarctatus Crawford, are new records for Nova Scotia (see Sheffield et al. 2003). A fourth species, Megachile pugnata Say, though not reported by Sheffield et al. (2003), was previously reported from Nova Scotia from two specimens by Ivanochko (1979). In 2001, 17 of the 18 species were collected; 9 species were collected in 2000 and 14 in 2002 (Table 1). The total number of bees reared from individual sites showed great variability within habitats (Table 2), but significant differences were not observed across habitat 


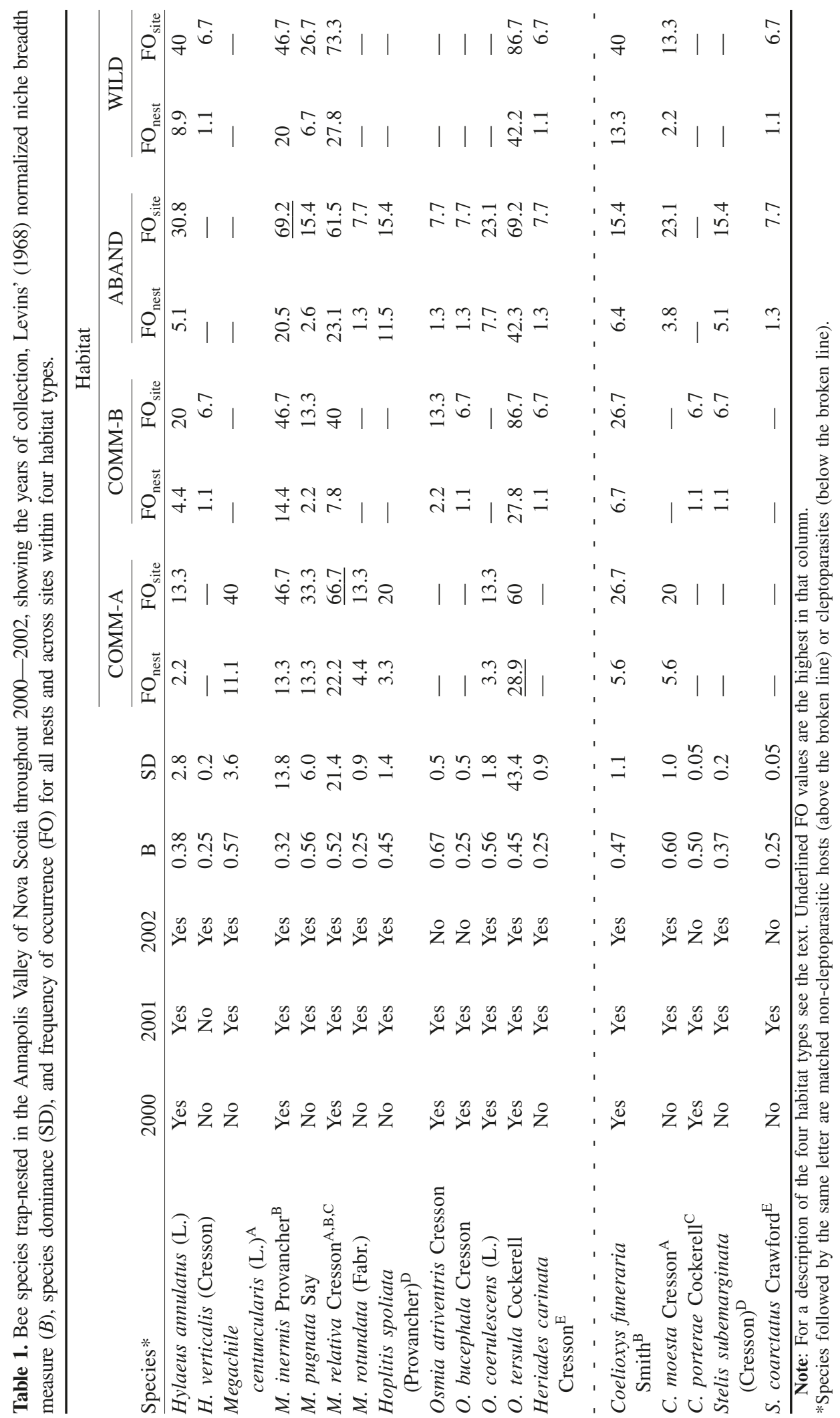


Table 2. Chi-square values for total bee numbers compared among sites within the four habitat types in the 3 years of the study.

\begin{tabular}{lccc}
\hline & 2000 & 2001 & 2002 \\
\hline COMM-A & 19.7 & 119.9 & 800.8 \\
COMM-B & 48.4 & 66.6 & 136.2 \\
ABAND & 38.4 & $59.2 *$ & $224.0^{*}$ \\
WILD & 98.5 & 47.5 & 823.9
\end{tabular}

Note: For a description of the four habitat types see the text. Critical values are as follows: $\chi_{0.05,4}^{2}=9.488$ and $\chi_{0.05,3}^{2}=7.815$ (for values with an asterisk) (Zar 1999).

categories $\left(F_{3,42}=1.13, P=0.347\right)$ (Table 3$)$. Three sites yielded more then 300 bees in 2002: sites A3 and A4 in the COMM-A habitat and D1 in the WILD habitat. The total number of bees reared from trap nests increased by a factor of 1.8 between 2000 (485 individuals) and 2001 (855 individuals) and by 3.1 between 2001 and 2002 (2762 individuals). Significantly more bees were collected per habitat in 2002 than in 2000 and 2001, but numbers did not differ between the latter 2 years $\left(F_{2,42}=11.39, P>\right.$ 0.001; Tukey's test, $P=0.05$ ) (Table 3). The WILD and COMM-A habitats yielded the greatest abundance of bees overall, although the ABAND habitat was also productive in 2002 (Table 3). No significant interactions between site and year were observed $\left(F_{6,42}=0.85, P=\right.$ $0.542)$.

In the WILD habitat, 10 species were collected in trap nests during the 3-year period, fewer than in all other habitat types (Fig. 3). The ABAND habitat supported the highest species richness (15 species), followed by COMMB (13 species) and COMM-A (12 species) (Fig. 3). However, no significant differences in the number of species per habitat were found $\left(F_{3,42}=1.44, P=0.244\right)$, although differences were observed among years $\left(F_{2,42}=9.91, P>\right.$ $0.001)$, with significantly more species per habitat in 2002 than were observed in 2000, and numbers in 2001 not differing significantly from those in either of those years (Tukey's test, $P=0.05)$. No significant interactions between site and year were observed $\left(F_{6,42}=1.71\right.$, $P=0.143)$. The maximum number of species collected at any site within the 3 years was 9 (COMM-A, site A3, in 2002). Two other COMM-A sites (A2 and A4) had moderate ( $\geq 7$ species) species diversity in 2002, as did one COMM-B site (B1), two ABAND sites (C3 in 2001, C6 in 2002), and one WILD site (D4).
Overall fecundity varied significantly among habitats $\left(\chi_{0.05,3}^{2}=76.75\right)$, being much higher than expected in the WILD habitat and lower than expected in the ABAND habitat, while the COMM$\mathrm{A}$ and COMM-B habitats yielded close to the expected number of bees (Fig. 4). No significant variation in the Berger-Parker dominance index was observed across habitats $\left(F_{3,42}=0.86, P=\right.$ $0.470)$, but variation was observed across years $\left(F_{2,42}=5.13, P=0.01\right)$, values being lower in 2000 than in 2002 (Tukey's test, $P=0.05$ ). No significant interactions between site and year were observed $\left(F_{6,42}=1.58, P=0.176\right)$. The most abundant species was Osmia tersula Cockerell, which accounted for $43.4 \%$ of the total bees reared from all sites in the 3 years (see SD values in Table 1) and was the most common species encountered in all habitats (Fig. 3). Osmia tersula was the most frequently collected species, using $27 \%-29 \%$ of the trap nests within the commercial orchards (COMM-A and COMM-B) and just over $42 \%$ in the ABAND and WILD habitats (see $\mathrm{FO}_{\text {nest }}$ values in Table 1). It was found in more sites per year $\left(\mathrm{FO}_{\text {site }}=60-86.7\right)$ than any other species, although Megachile relativa Cresson was slightly more widespread in the COMM-A habitat (Table 1). Megachile relativa was the second most abundant species $(\mathrm{SD}=21.4 \%)$, and with $M$. inermis Provancher $(\mathrm{SD}=13.8 \%)$ and $M$. pugnata $(\mathrm{SD}=$ $6.0 \%$ ) made up the majority of the remaining bees collected (Table 1). Stelis coarctatus was only observed in 2001 (Table 1).

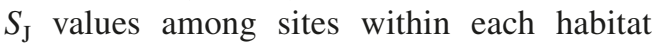
were low $(<0.45$ in all cases; data pooled across years), although the WILD habitat showed significantly higher compositional similarity than COMM-A and ABAND; no differences were observed among the other sites $\left(F_{3,92}=4.67, P=\right.$ 0.004; Tukey's test, $P=0.05$ ) (Fig. 5). Sites showed no predictable patterns of clustering based on species presence/absence, and sites classified within each of the four habitat categories showed high levels of dissimilarity, each site often appearing in separate groups containing sites from different habitat categories (Fig. 6).

\section{Nesting preferences}

Most bee species trap-nested showed a preference for nesting tubes with one or two diameters, as summarized by $B$ values, which were averaged for each species across the 3 years (Table 1). However, 8 of the 18 species provisioned/parasitized fewer than five nesting tubes within the 3 -year period. The $B$ value for 
Table 3. Summary statistics for trap nest captures, showing numbers of bees reared, numbers of species (mean \pm standard deviation (SD)), and minimum and maximum values observed within each habitat category for 20002002 and pooled for all years.

\begin{tabular}{|c|c|c|c|c|c|c|}
\hline \multirow[b]{2}{*}{ Year } & \multirow[b]{2}{*}{ Habitat* } & \multirow[b]{2}{*}{$n$} & \multicolumn{2}{|c|}{ Number of individuals } & \multicolumn{2}{|c|}{ Number of species } \\
\hline & & & Mean \pm SD & Range & Mean \pm SD & Range \\
\hline 2000 & COMM-A & 5 & $9.4 \pm 6.8$ & $0-19$ & $1.6 \pm 1.1$ & $0-3$ \\
\hline 2000 & COMM-B & 5 & $27.8 \pm 18.3$ & $15-59$ & $2.8 \pm 0.8$ & $2-4$ \\
\hline 2000 & ABAND & 5 & $21.4 \pm 14.3$ & $5-41$ & $2.0 \pm 1.0$ & $1-3$ \\
\hline 2000 & WILD & 5 & $38.4 \pm 30.7$ & $0-86$ & $2.4 \pm 1.5$ & $0-4$ \\
\hline 2001 & COMM-A & 5 & $64.0 \pm 59.8$ & $27-169$ & $4.0 \pm 1.6$ & $2-6$ \\
\hline 2001 & COMM-B & 5 & $21.6 \pm 18.8$ & $0-41$ & $2.2 \pm 1.6$ & $0-4$ \\
\hline 2001 & ABAND & 4 & $68.0 \pm 36.6$ & $30-118$ & $5.0 \pm 1.6$ & $3-7$ \\
\hline 2001 & WILD & 5 & $42.6 \pm 22.5$ & $14-64$ & $3.4 \pm 0.9$ & $3-5$ \\
\hline 2002 & COMM-A & 5 & $168.4 \pm 183.6$ & $0-400$ & $5.0 \pm 4.2$ & 0-9 \\
\hline 2002 & COMM-B & 5 & $71.4 \pm 49.3$ & $27-131$ & $3.4 \pm 1.9$ & $2-6$ \\
\hline 2002 & ABAND & 4 & $141.8 \pm 102.9$ & $72-291$ & $5.0 \pm 2.2$ & $2-7$ \\
\hline 2002 & WILD & 5 & $204.8 \pm 195.5$ & $13-513$ & $5.2 \pm 1.3$ & $3-6$ \\
\hline Pooled & COMM-A & 15 & $80.6 \pm 123.8$ & $0-400$ & $3.5 \pm 2.9$ & 0-9 \\
\hline Pooled & COMM-B & 15 & $40.3 \pm 37.6$ & $0-131$ & $2.8 \pm 1.5$ & $0-6$ \\
\hline Pooled & ABAND & 13 & $72.8 \pm 75.8$ & $5-291$ & $3.8 \pm 2.1$ & $1-7$ \\
\hline Pooled & WILD & 15 & $95.3 \pm 133.3$ & $0-513$ & $3.7 \pm 1.7$ & $0-6$ \\
\hline
\end{tabular}

*For a description of the four habitat types see the text.

Fig. 3. Rank-abundance plots of numbers of trap-nested bees from the four habitat types for 2000-2002. Species are coded as follows: 1, Hylaeus annulatus; 2, H. verticalis; 3, Megachile centuncularis; 4, M. inermis; 5, M. pugnata; 6, M. relativa; 7, M. rotundata; 8, Hoplitis spoliata; 9, Osmia atriventris; 10, O. bucephala; 11, O. coerulescens; 12, O. tersula; 13, Heriades carinata; 14, Coelioxys funeraria; 15, C. moesta; 16, C. porterae; 17, Stelis subemarginata; 18, S. coarctatus.

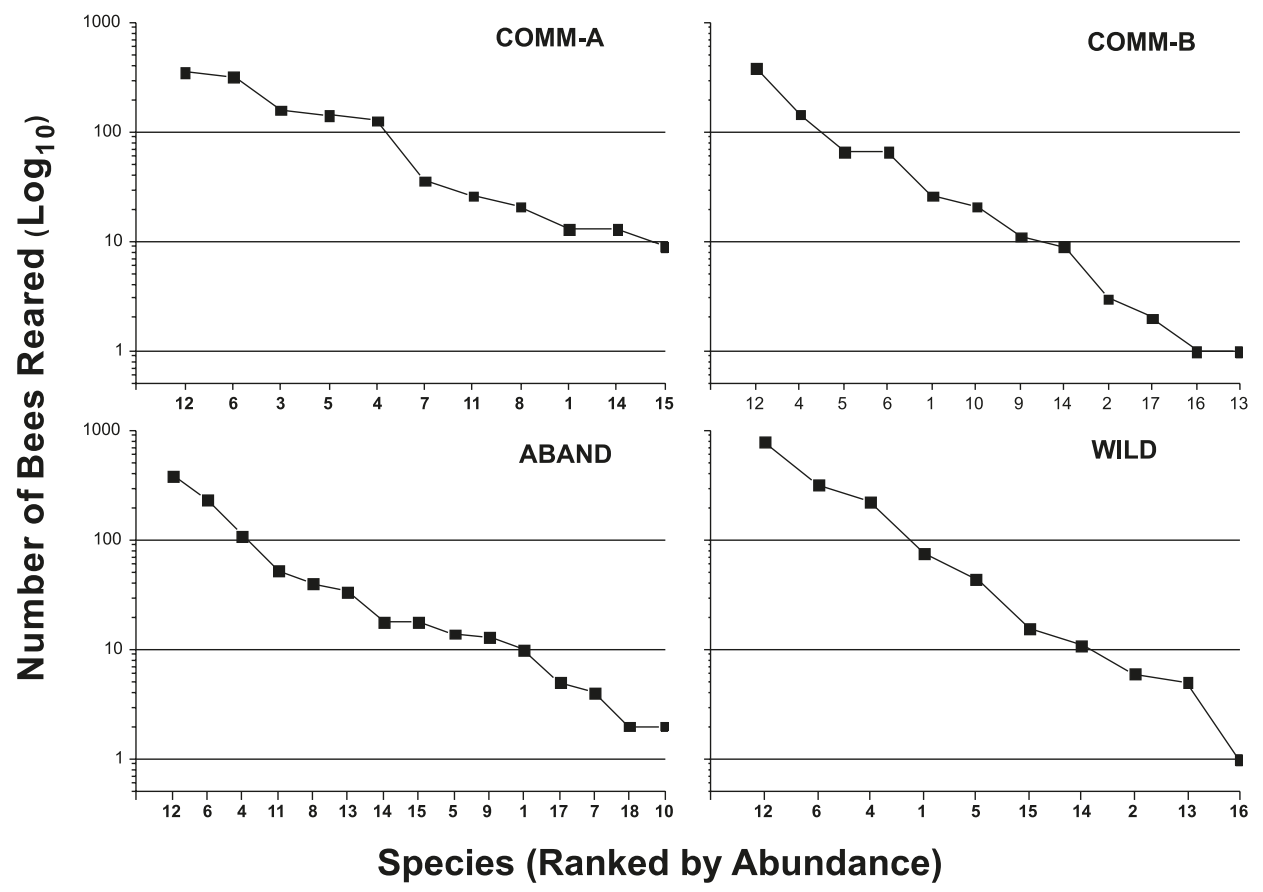

(C) 2008 Entomological Society of Canada 
Fig. 4. Observed and expected fecundity (i.e., number of bees produced), based on the number of nesting tubes provisioned in each habitat type; data for 2000-2002 are pooled. The ABAND and WILD habitats accounted for most of the deviation from expected values $\left(\chi_{0.05,3}^{2}=76.75\right)$.

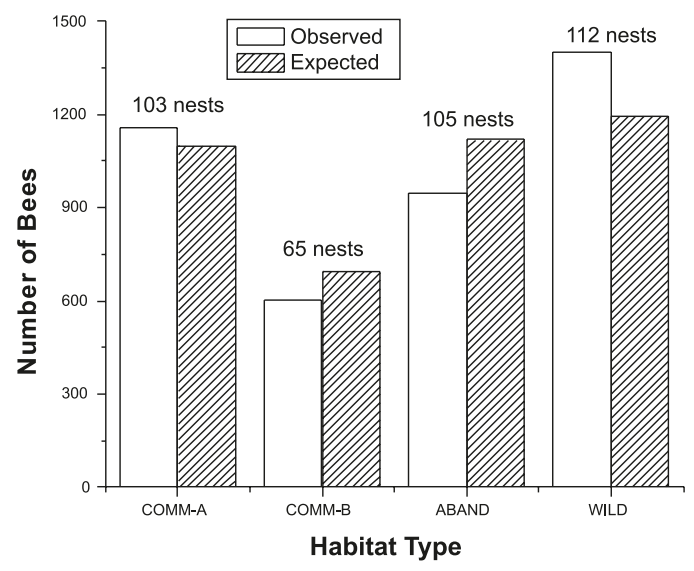

Fig. 5. Mean Jaccard's incidence-based similarity index values (mean $\pm \mathrm{SE}$ ) for within-habitat paired-site comparisons; values for 2000-2002 are pooled. Bars with the same letter are not significantly different (Tukey's test, $P=0.05)$.

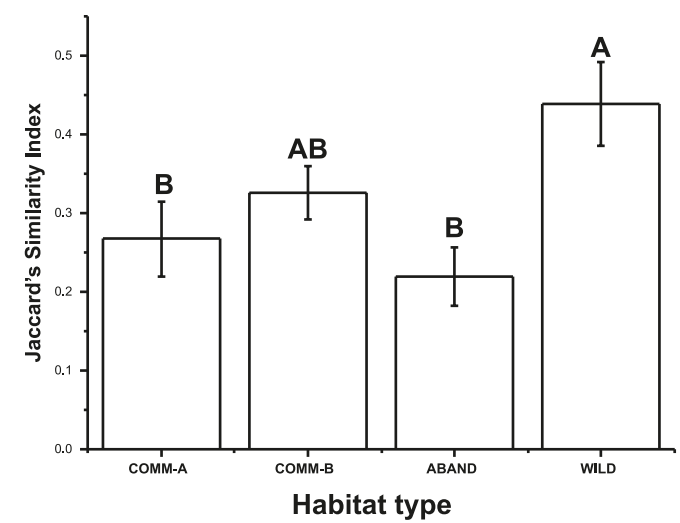

Fig. 6. Dendrogram of Jaccard's incidence-based dissimilarity $\left(1-S_{\mathrm{J}}\right)$ matrix produced by cluster analysis using average linkage methods (Seaby et al. 2004); data for 2001-2002 are pooled. Sites are listed at the right-hand side (see Appendix A for an explanation of codes).

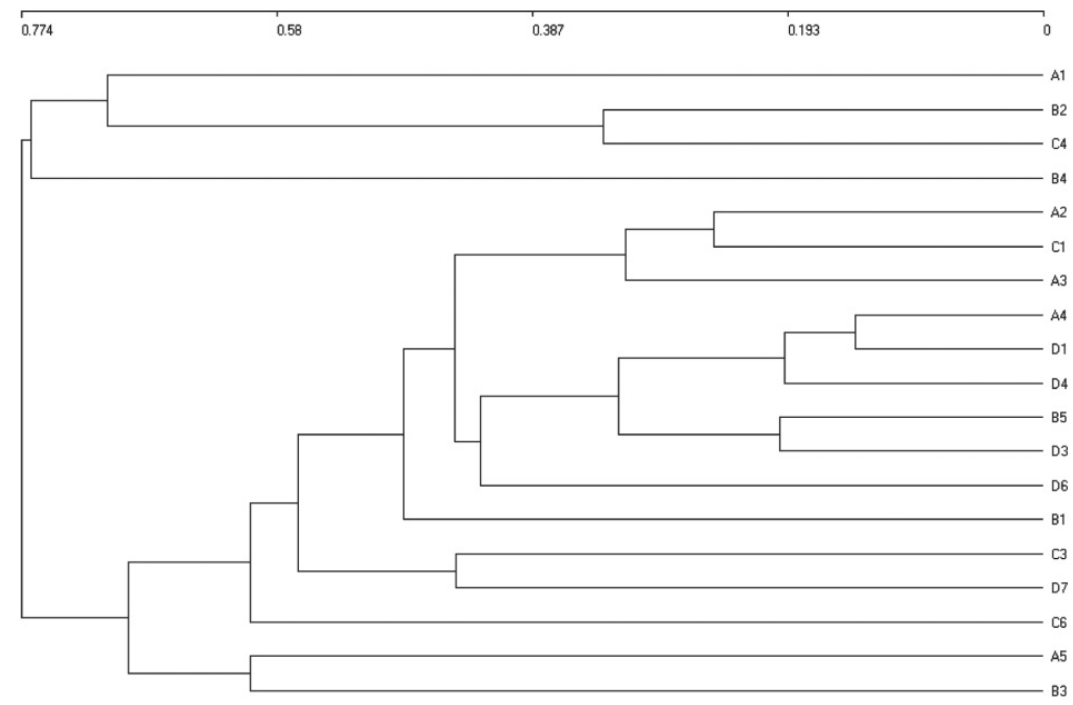

O. tersula (0.45) indicated a preference for tubes of two sizes: $5 \mathrm{~mm}$ diameter $(68 \%)$ and, to a lesser extent, $3 \mathrm{~mm}$ diameter $(29 \%)$ tubes were chosen throughout the 3-year study. Although trap-nested less frequently, the other two "small" Osmia species (O. coerulescens (L.) and $O$. atriventris Cresson) and $H$. carinata also preferred smaller nesting tubes, as did the slightly larger Hoplitis spoliata (Provancher) (Table 1). The only non-megachilid bees that were trap-nested, Hylaeus annulatus (L.) and $H$. verticalis, also chose smaller nesting tubes, although a few specimens of $H$. annulatus were reared out of one $9 \mathrm{~mm}$ diameter tube in 2002 .

The three commonest Megachile species also showed preferences, especially M. inermis, which was reared most frequently in $9 \mathrm{~mm}$ diameter nesting tubes $(B=0.32)$. Megachile relativa and $M$. pugnata $(B=0.52$ and $B=$ 0.56 , respectively) showed strongest preference 
for $7 \mathrm{~mm}$ diameter tubes, but were commonly reared out of 5 and $9 \mathrm{~mm}$ diameter tubes. Only one Megachile species, M. centuncularis (L.), was reared out of a $3 \mathrm{~mm}$ diameter nesting tube, although it too preferred larger sizes (Table 1 ). The smallest megachilid, $M$. rotundata, showed a narrow nesting preference, being reared exclusively from $5 \mathrm{~mm}$ diameter nesting tubes $(B=0.25)$.

The nest choices of cleptoparasitic Megachilidae were dictated by their hosts. Stelis submarginatus (Cresson) $(B=0.37)$ and $S$. coarctatus $(B=0.25)$ were reared out of small nesting tubes with their respective hosts, $H$. spoliata and $H$. carinata. Coelioxys species were reared from tubes of multiple sizes $(B \geq$ 0.47 for all three species), reflecting their habit of targeting multiple Megachile hosts (Table 1).

\section{Discussion}

The presence of nesting bees within a given habitat is ultimately related to its suitability, which is influenced by three main factors (after Westrich 1996): (1) the availability of nesting sites (and see Potts et al. 2005), (2) the availability of nest-building materials (especially for leafcutters and masons), and (3) sufficient food plants for nectar and pollen. These three resources not only influence the diversity of pollinators within a given habitat by meeting their specific needs, they also strongly affect the abundance and (or) fecundity of certain species through the quantities in which they occur (Müller et al. 2006; Williams and Kremen 2007). In this study, one of these resources, nesting sites, was made available to cavitynesting bees via trap nests.

Overall, the species collected in this survey (Table 1) were representative of Nova Scotia's cavity-nesting bee fauna (Sheffield et al. 2003); Sheffield (2006) and Cane et al. (2007) recently reviewed the nesting biology of many of these species. Species richness and abundance (i.e., total numbers reared) were expected to be highest within less managed habitats, high similarity was expected among sites within each habitat type, and differences were expected among habitat types based on the management practices in each. These hypotheses were not supported in our study. In fact, the WILD habitat had the lowest species richness (although not significantly so) of the four habitat types (Fig. 3). However, natural habitats within or adjacent to woodlands probably contain abundant natural nesting sites (e.g., Steffan-Dewenter and Leschke 2003; Morato and Martins 2006), which may decrease trap nest occupation (see Buschini 2006 and references therein). Buschini (2006) compared trap-nesting bees in natural communities in Brazil and found that species richness was lower in forest habitats than in more open swamps and grasslands, and this was attributed to natural-cavity use. To support this observation, other methods of assessing species richness within the same sites are required. However, a complimentary survey using yellow pan traps conducted simultaneously with this study at the same study sites (Sheffield 2006) suggests that many additional species are present and might be using natural nesting cavities within the WILD habitats (Table 4). Cavity-nesting species not utilizing trap nests were collected in pan traps in the WILD habitats, as were species showing a preference for bored or pithy stems, often at abundances several magnitudes higher than those in other habitats (Table 4). This is especially important when one considers the potential fecundity of each female collected in pan traps and its effects on bee population size in subsequent seasons. In our trap nest study, fecundity, measured as the number of bees produced per nesting tube, was much greater in the WILD habitats than in any other habitat (Fig. 4); the unrealized fecundity in the agricultural (and past agricultural) sites may reflect shortages of food plants in these habitats (Williams and Kremen 2007), as weed management occurred routinely, at least within the commercial orchards. Therefore, it seems likely that trap nest surveys alone (e.g., Klein et al. 2002; Steffan-Dewenter 2002; Tylianakis et al. 2006) provide only a partial picture of potential species richness and abundance of cavity-nesting bees when the results are compared across diverse landscapes.

Diversity and abundance of food plants are important - larger plant communities support larger bee populations and (or) greater fecundity of resident individuals (Müller et al. 2006; Williams and Kremen 2007). Often, competition for these food resources affects bee abundance (Forup and Memmott 2005) and fecundity (Paini and Roberts 2004), especially when the main competitors are effective resource exploiters like honey bees. A habitat rich in floral resources is necessary to support bee population growth (Westrich 1996; Potts et al. 2003; Müller et al. 2006), but management of orchards, particularly weed-control practices 




(C) 2008 Entomological Society of Canada 
within and adjacent to blocks, can have an impact on floral-food richness within these settings (Marshall and Moonen 2002; Williams and Kremen 2007), thereby affecting the levels of pollination provided by native bees (Kremen et al. 2002). Herbicides targeting broad-leaved weeds can be particularly damaging to bees, which rely on flowers for pollen and nectar. Mowing of vegetation also can have an effect on food-plant availability, although SteffanDewenter and Leschke (2003) suggest that this practice may increase the richness of flowering herbs in orchard meadows above levels observed in abandoned ones.

In intensely managed systems, wooded or natural corridors and bordering habitats rich in flowering plants are known to promote diversity of beneficial organisms (Marshall and Moonen 2002) including bees (Corbet 1995; Banaszak 2000). Surprisingly, then, the COMM-A habitat yielded many bees, second only to the WILD habitat (Table 3 ). It is obvious that some of the sites within the COMM-A habitat were much more suitable for bees than were others, as fecundity was not uniform (Table $2 ; \chi^{2}$ values are exceptionally high for 2001 and 2002), indicating that food plants were probably within the flight range of some species (see Gathmann and Tscharntke 2002) in a few sites. However, more species were observed in both the COMM-B and ABAND habitats, in both the trap nest (albeit not significant) and the pan trap surveys (Table 4), indicating that natural borders (and lack of chemicals) are indeed important to bee populations. In agro-ecosystems, the history of each site and the existing management practices used within it can ultimately prove to be the factors that influence bee diversity and abundance (Marshall and Moonen 2002). By using practices that are more friendly to beneficial organisms (i.e., appropriate choice of pesticide, time of application, etc.), and by promoting diverse plant communities in "no-pesticide zones", cavity-nesting bees can be encouraged to nest in and adjacent to agricultural landscapes (Kremen et al. 2002). Under such conditions, the species richness and fecundity of cavity-nesting bees within a site would be influenced by the presence of nesting sites, both natural and artificial.

Based on our findings, at least 18 indigenous species of cavity-nesting bees can be trapnested throughout a range of habitats in the Annapolis Valley, possibly more if pithy and (or) hollow stems were to be used in addition to trap nests with paper nesting tubes (Table 4). Even under conditions of commercial orchard management, a diverse assemblage of bees was trap-nested and exhibited species richness similar to that in unsprayed and (or) wild habitats. In addition, several species (i.e., O. tersula, $M$. inermis, $M$. centuncularis, and $M$. relativa) appear to be agrobionts - doing as well or better in agro-ecosystems than in wild sites. Despite the fact that all occupants of trap nests were removed without replacement from the sites each year, the number of bees reared each year continued to increase significantly, especially in 2002 .

This study demonstrated the potential of $O$. tersula as a new megachilid bee for commercial pollinator management in orchards. In Nova Scotia, Osmia spp. are the only Megachilidae active early in the spring after overwintering as adults, apparently a derived characteristic within the Megachilidae (Bosch et al. 2001). The remaining members of the megachilid tribes Osmiini, Anthidiini, and Megachilini in Nova Scotia are strictly summer bees; it would be difficult to synchronize their emergence with the pollination period of spring-flowering crops, including most tree-fruit species. Osmia tersula was commonly trap-nested in high numbers in many sites across all habitats (Table 1, Fig. 3). In addition, its early-season emergence and the fact that it visits apple flowers (Sheffield et al. 2003) as a pollen source (C.S. Sheffield, unpublished data) suggest its potential as a manageable pollinator of this crop. Knowing that several potentially manageable pollinators are in these systems is encouraging from the standpoint of increasing their numbers. The information gained concerning the nesting biology of these species, including tunnel diameters preferred for maximizing fecundity and promoting a desirable sex ratio, and flower-use patterns, provides the first steps in promoting and developing cavity-nesting species for pollination management.

\section{Acknowledgements}

This research was conducted as part of C.S. Sheffield's graduate studies under the supervision of P.G. Kevan, University of Guelph, Guelph, Ontario. We thank all the orchardists and landowners who gave us access to their property over the 3-year study period. Thanks are also extended to the employees of the Atlantic Food and Horticulture Research Centre, 
Agriculture and Agri-Food Canada, Kentville, Nova Scotia, for support and encouragement during the study, and to Laurence Packer, York University, Toronto, Ontario, for helpful comments during the preparation of the manuscript. Funding for this study came from several AgriFocus 2000 Technology Development Project grants and an AgriFutures grant to R.F. Smith and C.S. Sheffield. Thanks are also extended to three anonymous reviews for their helpful comments.

\section{References}

Banaszak, J. 2000. Effect of habitat heterogeneity on the diversity and density of pollinating insects. In Interchanges of insects between agricultural and surrounding landscapes. Edited by B. Ekbom, M.E. Irwin, and Y. Robert. Kluwer Academic Publishers, Dordrecht, the Netherlands. pp. 123140.

Bosch, J., and Kemp, W.P. 2001. How to manage the blue orchard bee as an orchard pollinator. Sustainable Agriculture Network Handbook Series No. 5.

Bosch, J., Maeta, Y., and Rust, R. 2001. A phylogenetic analysis of nesting behavior in the genus Osmia (Hymenoptera: Megachilidae). Annals of the Entomological Society of America, 94: 617627.

Buschini, M.L.T. 2006. Species diversity and community structure in trap-nesting bees in southern Brazil. Apidologie, 37: 58-66.

Cane, J.H., Griwold, T., and Parker, F.D. 2007. Substrates and materials used for nesting by North American Osmia bees (Hymenoptera: Apiformes: Megachilidae). Annals of the Entomological Society of America, 100: 350-358.

Corbet, S.A. 1995. Insects, plants and succession: advantages of long-term set aside. Agriculture, Ecosystems and Environment, 53: 201-217.

Craig, W. 1998. Tree fruit census of the Annapolis Valley. Production Technology Branch, Nova Scotia Department of Agriculture and Marketing, Kentville, Nova Scotia.

Forup, M.L., and Memmott, J. 2005. The relationship between the abundances of bumblebees and honeybees in a native habitat. Ecological Entomology, 30: 47-57.

Free, J.B. 1993. Insect pollination of crops. 2nd ed. Academic Press, San Diego, California.

Fye, R.E. 1965. Biology of Apoidea taken in trap nests in northwestern Ontario (Hymenoptera). The Canadian Entomologist, 97: 863-877.

Gathmann, A., and Tscharntke, T. 2002. Foraging ranges of solitary bees. Journal of Animal Ecology, 71: 757-764.

Heard, T.A. 1999. The role of stingless bees in crop pollination. Annual Review of Entomology, 44: 183-206.
Ivanochko, M. 1979. Taxonomy, biology and alfalfa pollinating potential of Canadian leaf-cutting bees: genus Megachile Latreille (Hymenoptera: Megachilidae). M.Sc. thesis, McGill University, Montréal, Quebec.

Kevan, P.G. 2001. Pollination: a plinth, pedestal, and pillar for terrestrial productivity: the why, how, and where of pollination protection, conservation, and promotion. In Bees and crop pollination crisis, crossroads, conservation. Edited by C.S. Stubbs and F.A. Drummond. Thomas Say Publications in Entomology: Proceedings of the Entomological Society of America. Entomological Society of America, Lanham, Maryland. pp. 7-68.

Kevan, P.G., and Baker, H.G. 1983. Insects as flower visitors and pollinators. Annual Review of Entomology, 28: 407-53.

Kevan, P.G., Straver, W.A., Offer, M., and Laverty, T.M. 1991. Pollination of greenhouse tomatoes by bumblebees in Ontario. Proceedings of the Entomological Society of Ontario, 122: 15-19.

Klein, A.-M., Steffan-Dewenter, I., Buchori, D., and Tscharntke, T. 2002. Effects of land use intensity in tropical agroforestry systems on coffee flowervisiting and trap-nesting bees and wasps. Conservation Biology, 16: 1003-1014.

Kremen, C., Williams, N.M., and Thorp, R.W. 2002. Crop pollination from native bees at risk from agricultural intensification. Proceedings of the National Academy of Sciences, 99: 16812-16816.

Krombein, K.V. 1967. Trap-nesting wasps and bees: life histories, nests, and associates. Smithsonian Institution Press, Washington, D.C.

Levins, R. 1968. Evolution in changing environments. Princeton University Press, Princeton, New Jersey.

Magurran, A.E. 2004. Measuring biological diversity. Blackwell Publishing, Malden, Massachusetts.

Marshall, E.J.P., and Moonen, A.C. 2002. Field margins in northern Europe: their function and interactions with agriculture. Agriculture, Ecosystems and Environment, 89: 5-21.

Michener, C.D. 1947. A revision of the American species of Hoplitis (Hymenoptera, Megachilidae). Bulletin of the American Museum of Natural History, 89: $257-317$.

Minitab Inc. 2000. MINITAB ${ }^{\circledR}$ statistical software. Release 13 [computer program]. Minitab Inc., State College, Pennsylvania.

Morato, E.F., and Martins, R.P. 2006. An overview of proximate factors affecting the nesting behavior of solitary wasps and bees (Hymenoptera: Aculeata) in preexisting cavities in wood. Neotropical Entomology, 35: 285-298.

Müller, A., Diener, S., Schnyder, S., Stutz, K., Sedivy, C., and Dorn, S. 2006. Quantitative pollen requirements of solitary bees: implications for bee conservation and the evolution of bee-flower relationships. Biological Conservation, 130: 604-615. 
Paini, D.R., and Roberts, J.D. 2004. Commercial honey bees (Apis mellifera) reduce the fecundity of an Australian native bee (Hylaeus alcyoneus). Biological Conservation, 123: 103-112.

Potts, S.G., Vulliamy, B., Dafni, A., Ne'eman, G., and Wilmer, P. 2003. Linking bees and flowers: how do floral communities structure pollinator communities? Ecology, 84: 2628-2642.

Potts, S.G., Vulliamy, B., Roberts, S., O'Toole, C., Dafni, A., Ne'eman, G., and Willmer, P. 2005. Role of nesting resources in organizing diverse bee communities in a Mediterranean landscape. Ecological Entomology, 30: 78-85.

Seaby, R.M.H., Henderson, P.A., and Prendergast, J.R. 2004. Community analysis package. Version 3.2 [computer program]. Pisces Conservations Ltd., Lymington, United Kingdom.

Sheffield, C.S. 2006. Diversity and management of bees for the pollination of apple in the Annapolis Valley of Nova Scotia. Ph.D. thesis, University of Guelph, Guelph, Ontario.

Sheffield, C.S., Kevan, P.G., Smith, R.F., Rigby, S.M., and Rogers, R.E.L. 2003. Bee species of Nova Scotia, Canada, with new records and notes on bionomics and floral relations (Hymenoptera: Apoidea). Journal of the Kansas Entomological Society, 76: 357-384.

Steffan-Dewenter, I. 2002. Landscape context affects trap-nesting bees, wasps, and their natural enemies. Ecological Entomology, 27: 631-637.

Steffan-Dewenter, I. 2003. Importance of habitat area and landscape context for species richness of bees and wasps in fragmented orchard meadows. Conservation Biology, 17: 1036-1044.

Steffan-Dewenter, I., and Leschke, K. 2003. Effects of habitat management on vegetation and aboveground nesting bees and wasps of orchard meadows in Central Europe. Biodiversity and Conservation, 12: 1953-1968.

Stephen, W.P. 2003. Solitary bees in North American Agriculture: a perspective. In For nonnative crops, whence pollinators of the future? Edited by K. Strickler and J.H. Cane. Thomas Say Publications in Entomology: Proceedings of the Entomological Society of America. Entomological Society of America, Lanham, Maryland. pp. 41-66.
Stubbs, C.S., and Drummond, F.A. 2001. Strategies for conserving mason bees. In Bees and crop pollination - crisis, crossroads, conservation. Edited by C.S. Stubbs and F.A. Drummond. Thomas Say Publications in Entomology: Proceedings of the Entomological Society of America. Entomological Society of America, Lanham, Maryland. pp. 95-112.

Thorp, R.W. 2003. Bumble bees (Hymenoptera: Apidae): commercial use and environmental concerns. In For nonnative crops, whence pollinators of the future? Edited by K. Strickler and J.H. Cane. Thomas Say Publications in Entomology: Proceedings of the Entomological Society of America. Entomological Society of America, Lanham, Maryland. pp. 21-40.

Torchio, P.F. 2003. Development of Osmia lignaria (Hymenoptera: Megachildae) as a managed pollinator of apple and almond crops: a case history. In For nonnative crops, whence pollinators of the future? Edited by K. Strickler, and J.H. Cane. Thomas Say Publications in Entomology: Proceedings of the Entomological Society of America. Entomological Society of America, Lanham, Maryland. pp. 67-84.

Tylianakis, J.M., Klein, A.-M., Lozada, T., and Tscharntke, T. 2006. Spatial scale of observation affects $\alpha, \beta$ and $\gamma$ diversity of cavity-nesting bees and wasps across a tropical land-use gradient. Journal of Biogeography, 33: 1295-1304.

Westrich, P. 1996. Habitat requirements of central European bees and the problems of partial habitats. In The conservation of bees. Edited by A. Matheson, S.L Buchmann, C. O'Toole, P. Westrich, and I.H. Williams. Linnean Society and International Bee Research Association and Academic Press, London, United Kingdom. pp. 1-16.

Williams, N.M. and Kremen, C. 2007. Resource distributions among habitats determine solitary bee offspring production in a mosaic landscape. Ecological Applications, 17: 910-921.

Zar, J.H. 1999. Biostatistical analyis. 4th ed. Prentice Hall, Upper Saddle River, New Jersey.

\section{Appendix A}

Appendix appears on the following page. 
Table A1. Coding and locality information for sites in four habitats used in trap nest and pan trap surveys in 2000-2002.

\begin{tabular}{lccccc}
\hline \multirow{4}{*}{ Habitat } & Site & & & \\
& code & Years used & Location & County & Coordinates \\
\hline COMM-A & A1 & All & Melvern Square & Annapolis & $44.9892^{\circ} \mathrm{N}, 64.9971^{\circ} \mathrm{W}$ \\
& A2 & All & Pereau & Kings & $45.1872^{\circ} \mathrm{N}, 64.4030^{\circ} \mathrm{W}$ \\
& A3 & All & Upper Canard & Kings & $45.1290^{\circ} \mathrm{N}, 64.4617^{\circ} \mathrm{W}$ \\
& A4 & All & Hortonville & Kings & $45.1044^{\circ} \mathrm{N}, 64.2931^{\circ} \mathrm{W}$ \\
& A5 & All & Grafton & Kings & $45.0869^{\circ} \mathrm{N}, 64.6677^{\circ} \mathrm{W}$ \\
COMM-B & B1 & All & Somerset & Kings & $45.0836^{\circ} \mathrm{N}, 64.7322^{\circ} \mathrm{W}$ \\
& B2 & All & Pereau & Kings & $45.1904^{\circ} \mathrm{N}, 64.4153^{\circ} \mathrm{W}$ \\
& B3 & All & Wolfville & Kings & $45.0792^{\circ} \mathrm{N}, 64.3814^{\circ} \mathrm{W}$ \\
& B4 & All & Morristown & Kings & $44.9810^{\circ} \mathrm{N}, 64.7545^{\circ} \mathrm{W}$ \\
& B5 & All & West Black Rock & Kings & $45.1298^{\circ} \mathrm{N}, 64.7383^{\circ} \mathrm{W}$ \\
& C1 & All & West Black Rock & Kings & $45.1392^{\circ} \mathrm{N}, 64.7302^{\circ} \mathrm{W}$ \\
& C2 & 2000 & Gaspereau & Kings & $45.0693^{\circ} \mathrm{N}, 64.3266^{\circ} \mathrm{W}$ \\
& C3 & All & Lockhartville & Kings & $45.0850^{\circ} \mathrm{N}, 64.2337^{\circ} \mathrm{W}$ \\
& C4 & All & Kentville & Kings & $45.0628^{\circ} \mathrm{N}, 64.4881^{\circ} \mathrm{W}$ \\
& C5 & 2000 & Green Acres & Annapolis & $45.0250^{\circ} \mathrm{N}, 64.9299^{\circ} \mathrm{W}$ \\
& C6 & $2001-2002$ & Upper Canard & Kings & $45.1350^{\circ} \mathrm{N}, 64.4890^{\circ} \mathrm{W}$ \\
& D1 & All & Lockhartville & Kings & $45.0727^{\circ} \mathrm{N}, 64.2198^{\circ} \mathrm{W}$ \\
& D2 & 2000 & Burlington & Kings & $45.0765^{\circ} \mathrm{N}, 64.7940^{\circ} \mathrm{W}$ \\
& D3 & All & Middleton & Annapolis & $44.9650^{\circ} \mathrm{N}, 65.0575^{\circ} \mathrm{W}$ \\
& D4 & All & East Torbrook & Kings & $44.9266^{\circ} \mathrm{N}, 64.9301^{\circ} \mathrm{W}$ \\
& D5 & 2000 & Kentville & Kings & $45.0793^{\circ} \mathrm{N}, 64.4828^{\circ} \mathrm{W}$ \\
& D6 & $2001-2002$ & Avonport & Kings & $45.1198^{\circ} \mathrm{N}, 64.2730^{\circ} \mathrm{W}$ \\
& D7 & $2001-2002$ & Aylesford & Kings & $44.9783^{\circ} \mathrm{N}, 64.8103^{\circ} \mathrm{W}$ \\
\hline
\end{tabular}

Note: For a description of the four habitat types see the text. 